
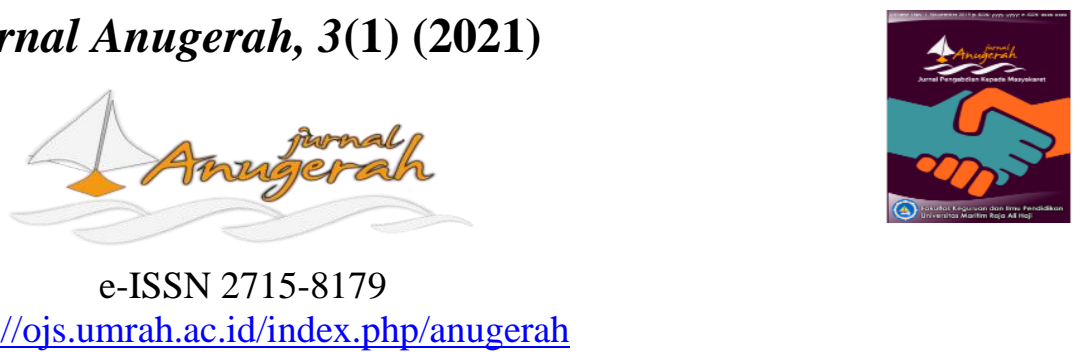

https://ojs.umrah.ac.id/index.php/anugerah

\title{
Pendampingan Pembuatan Hand Sanitizer pada Masyarakat Pembelajar Pendidikan Kimia pasca Pandemi COVID-19 di Kota Tanjungpinang
}

\author{
Nina Adriani", Eka Putra Ramdhani, Fitriah Khoirunnisa, Friska Septiani Silitonga, Hilfi Pardi, Dina \\ Fitriyah, Rita Fitriani \\ Program Studi Pendidikan Kimia, Universitas Maritim Raja Ali Haji \\ Tanjungpinang, Kepulauan Riau 29115, Indonesia \\ *e-mail korespondensi: nina.adriani@umrah.ac.id
}

Pengiriman: 22 Maret 2021; Diterima: 23 Mei 2021; Publikasi: 30 Mei 2021

DOI: https://doi.org/10.31629/anugerah.v3i1.3150

\begin{abstract}
Abstrak
Virus corona (COVID-19) menyebar dengan pesat di Indonesia sejak pertengahan Maret 2020, sehingga menuntut pemerintah untuk mencari solusi bagi mengurangi dampak penyebaran virus ini. Salah satu cara yang efektif adalah selalu menjaga kebersihan tubuh dengan selalu menggunakan hand sanitizer. Hand sanitizer merupakan cairan pembersih kuman yang digunakan pada tangan dan dapat membunuh kuman secara singkat karena kandungan yang terdapat dalam hand sanitizer berupa zat kimia yang berkonsentrasi tinggi seperti alkohol. Pasca pandemi COVID-19, cairan hand sanitizer sulit ditemukan karena kebutuhan yang sangat tinggi oleh seluruh masyarakat, sehingga hal ini menjadi pencetus institusi untuk mengajak akademisi untuk berperan aktif dalam membuat hand sanitizer yang dapat digunakan oleh masyarakat yang membutuhkan. Oleh karena itu dosen prodi Pendidikan Kimia UMRAH mendampingi mahasiswa Pendidikan kimia dalam membuat hand sanitizer yang dapat digunakan pada pandemi COVID-19 dan dapat digunakan oleh masyarakat umum. Pembuatan hand sanitizer ini menggunakan bahan-bahan seperti alkohol, hidrogen peroksida dan aloevera yang dilakukan di laboratorium Marine Chemistry, Universitas Maritim Raja Ali Haji. Produk hand sanitizer dapat digunakan oleh masyarakat umum melalui distribusi oleh satgas Kota Tanjungpinang, yayasan kesehatan masyarakat, puskesmas dan baznas Kota Tanjungpinang. Hal ini diharapkan dapat menjadi salah satu solusi dalam mengurangi penyebaran virus COVID-19 di kota Tanjungpinang.
\end{abstract}

Kata kunci: hand sanitizer; COVID-19; Tanjungpinang

\begin{abstract}
The corona virus (COVID-19) has spread rapidly in Indonesia since mid-March 2020, thus demanding the government to find solutions to reduce the impact of the spread. One effective way is to always maintain body hygiene by always using a hand sanitizer. Hand sanitizer is a germicidal liquid that is used on hands and can quickly remove germs. In the COVID-19 pandemic, hand sanitizer liquid is difficult to find because of the very high need for the whole community, so this has sparked the institution to invite academics to play a role in making hand sanitizers that can be used by people in need. Therefore, UMRAH Chemistry Education study program lecturers assist chemistry education students in making hand sanitizers that can be used in the COVID-19 pandemic and can be used by the general public. The making of this hand sanitizer used materials such as alcohol, hydrogen peroxide and aloe vera which is carried out in the Marine Chemistry Laboratory, Raja Ali Haji Maritime University. Hand sanitizer products can be used by the general public through distribution by the Tanjungpinang City task force, public health foundations, community health centers
\end{abstract}


JURNAL ANUGERAH, Mei 2021; Vol. 3(1): 49-56

e-ISSN 2715-8179

and the Tanjungpinang City Baznas. This is expected to be one of the solutions in reducing the spread of the COVID-19 virus in the city of Tanjungpinang.

Keywords: hand sanitizer; COVID-19; Tanjungpinang

\section{Pendahuluan}

Sejak pertengahan maret tahun 2020 lalu, virus corona (COVID-19) mulai menyebar di Indonesia dan kasusnya yang terus meningkat (Andhani, dkk, 2020). Berbagai gejala dapat menjadi tanda bagi yang terpapar virus seperti kurang sehat, suhu tubuh yang meninggi di atas $37^{\circ} \mathrm{C}$, serta sesak pada pernapasan (Ervianingsih, dkk, 2020). Pemaparan virus COVID-19 ini sangat mudah sekali terjadi, hanya karena percikan dari yang terpapar pada saat berbicara maupun bersin maka orang lain pun dapat terpapar juga. Sehingga disarankan untuk menghindari dari terpapar langsung, maka sebaiknya menggunakan masker di mana pun kita berada. Biasanya kurang dari 14 hari, gejala yang mengindikasi seseorang terpapar virus akan timbul.

Diagnosis yang disebabkan oleh virus COVID-19 bisa menggunakan uji sampel dahak atau usap nasofaring atau yang disebut uji rRTPCR yaitu sampel dahak diambil dari dalam hidung dan hasil tes dapat diketahui setelah 1 jam hingga 2 hari kemudian. Selain menggunakan sampel dahak, pengambilan sampel darah juga digunakan untuk memeriksa antibodi pada tubuh yang terpapar (Andhani, dkk, 2020). Hebatnya, virus COVID-19 ini memiliki ketahanan yang kuat pada suhu $26^{\circ} \mathrm{C}-27^{\circ} \mathrm{C}$, ia dapat bertahan hingga beberapa hari. Hal ini tentu mempermudah virus tersebut dapat menyebar ketika seseorang berada di sekitar virus atau memegang benda yang sudah terpapar. Hal ini menyebabkan WHO menyarankan beberapa solusi untuk mengurangi terjadinya penyebaran yang drastis yaitu masyarakat diminta untuk selalu hidup sehat, membersihkan Kesehatan tangan, tetapi ketika berada diluar rumah diminta untuk menggunakan hand sanitizer. Selain itu diharap masyarakat tidak berkumpul dan menjaga jarak untuk menghindari terpapar langsung dari orang lain ketika mereka berbicara atau bersin, wajib menggunakan masker selama berada di luar rumah dan melaksanakan aktivitas, serta menghindari untuk memegang hidung dan wajah langsung dengan tangan.

Demi mengurangi penyebaran terhadap inveksi COVID-19 ini, dilakukan suatu tindakan berupa social distancing di setiap wilayah baik pada skala lokal, nasional maupun internasional di setiap negara. Hal ini dilakukan untuk memutuskan serta mengurangi jumlah yang terpapar virus. Jarak aman antar individu disarankan yaitu tidak kurang dari dua meter dan tidak melaksanakan kegiatan yang sifatnya berkumpul dengan banyak orang. Tindakan yang bertujuan untk pencegahan penyebaran virus harus dilaksanakan sesegera mungkin, serta sesuai juga dengan Undang-Undang No. 6 Tahun 2018 yaitu tentang karantina kesehatan di mana masyarakat wajib mengurangi dan membatasi kegiatan yang bersifat sosial (Telaumbanua, 2020). Supaya tujuan pencegahan terhadap penyebaran virus COVID-19 ini dapat berjalan maksimal, peran dari setiap masyarakat adalah hal yang terpenting. Karena tanpa adanya usaha untuk mencegah, maka virus dapat menyebar dengan cepat. Tetap selalu menjaga aktivitas dengan berada di rumah, selalu memakai masker, menjaga kesehatan dengan banyak mengonsumsi air putih dan vitamin, selalu menjaga kesehatan tubuh dengan mencuci tangan dan memakai hand sanitizer merupakan hal-hal yang paling baik untuk dilakukan saat ini (Syafrida, 2020).

Pada cairan pembersih tangan seperti hand sanitizer sudah mulai digunakan secara meluas karena fungsinya dapat menjaga kebersihan tangan dari kuman dan lebih gampang dalam menggunakannya. Di berbagai tempat dan fasilitas umum juga sudah banyak disediakan (Radji, dkk, 2007). Kandungan yang terdapat pada hand sanitizer ini berupa senyawa alkohol dan fenol yang sifatnya membentuk koagulan pada kuman sehingga dapat membunuh kuman yang terpapar di kulit. Selain itu hand sanitizer juga biasanya ditambahkan pelembut dan pewangi yang biasanya dari bahan alam seperti jeruk, lidah buaya dan sebagainya untuk menmabah kesegaran ketika menggunakannya. Terutama di tempat-tempat makan, hand sanitizer 
selalu tersedia karena fungsinya yang praktis dan bagus untuk membunuh kuman sebelum kita mengonsumsi makanan (Fatimah \& Ardiani, 2018).

Memaksimalkan penggunaan hand sanitizer ketika sedang berada di luar rumah dan beraktivitas merupakan salah satu tindakan yang dapat mencegah terhadap penyebaran virus COVID-19. Berselangnya waktu, jumlah ketersediaan hand sanitizer pun menipis karena kebutuhan akan hand sanitizer sangat tinggi, sehingga menyebabkan sulitnya menemukan hand sanitizer di berbagai swalayan. Walaupun tersedia, harga hand sanitizer juga melonjak tinggi. Oleh karena itu, peran institusi dapat membantu mengurangi kesenjangan terhadap kebutuhan hand sanitizer dengan membuat hand sanitizer sendiri untuk membantu masyarakat kota Tanjungpinang.

Permasalahan yang terjadi di kota Tanjungpinang adalah meningkatnya kebutuhan akan penggunaan hand sanitizer yang dibutuhkan masyarakat karena jumlahnya yang sangat sedikit, sehingga dibutuhkan peran selain industri untuk menghasil hand sanitizer baru yang dapat digunakan. Oleh karena itu Universitas Maritim Raja Ali Haji meminta program studi Pendidikan Kimia untuk membuat hand sanitizer bagi mengatasi masalah ini. Dosen-dosen di prodi Pendidikan Kimia melakukan kegiatan pengabdian kepada masyarakat dengan cara melakukan kegiatan pendampingan pada mahasiswa Pendidikan Kimia dalam membuat hand sanitizer. Pendampingan ini bertujuan untuk memberikan kesempatan kepada mahasiswa Pendidikan Kimia untuk mempraktikkan ilmu-ilmu kimia yang telah didapat secara teori di kelas dengan menggunakan analisis kimia dan perhitungan kimia langsung di laboratorium. Selain itu pendampingan ini bertujuan untuk mengajarkan kepada mahasiswa bahwa penggunaan aloevera sebagai bahan alami dapat dimanfaatkan pada pembuatan hand sanitizer yang bertujuan sebagai bahan pelembab. Tujuan akhir dari kegiatan pengabdian ini adalah untuk membantu dan menambah ketersediaan hand sanitizer sehingga dapat dimanfaatkan oleh masyarakat umum di kota Tanjungpinang.

\section{Metode}

Kegiatan pengabdian kepada masyarakat berupa kegiatan pendampingan yang didampingi oleh dosen-dosen prodi Pendidikan kimia pada mahasiswa Pendidikan Kimia yang berjumlah 10 orang mahasiswa untuk membuat hand sanitizer di laboratorium Marine Chemistry, Universitas Maritim Raja Ali Haji. Kegiatan ini dilaksanakan selama 2 minggu hingga produk selesai didistribusikan. Kegiatan pendampingan ini dimulai dengan mendampingi mahasiswa mensterilkan alat-alat yang akan digunakan di laboratorium, mempersiapkan alat dan bahan yang digunakan, menimbang dan mengukur jumlah bahan serta mendampingi selama pembuatan hand sanitizer. Di akhir kegiatan adalah dosen mendampingi mahasiswa selama pengemasan hand sanitizer serta mendistribusikannya.

Tahapan pelaksanaan kegiatan pengabdian dijelaskan secara lebih detail sebagai berikut:

1. Proses pembuatan hand sanitizer sesuai dengan resep BPOM

Bahan-bahan:

a. Alkohol berupa etanol atau isopropanol

b. Hidrogen Peroksida dengan kadar 3\%

c. Aloevera sebagai pengganti gliserol

Alat:

a. Gelas ukur dengan ukuran $25 \mathrm{~mL}, 50 \mathrm{~mL}$ dan $1000 \mathrm{~mL}$

b. Pengaduk

c. Gelas bikar

Prosedur: 
JURNAL ANUGERAH, Mei 2021; Vol. 3(1): 49-56

e-ISSN 2715-8179

a. Alkohol berupa etanol atau isopropanol yang memiliki kadar $96 \%$ disiapkan dalam gelas ukur berukuran $1000 \mathrm{~mL}$.

b. Memasukkan hidrogen peroksida berkadar $3 \%$ sebanyak $41,7 \mathrm{~mL}$ ke dalam senyawa alkohol.

c. Menambahkan aloevera sebanyak $14,5 \mathrm{~mL}$ ke dalam campuran alhohol dan hidrogen peroksida.

d. Maksimalkan dengan menambahkan air suling hingga campuran maksimal $1000 \mathrm{~mL}$ dan aduk merata.

e. Pindahkan ke dalam kemasan botol atau jeriken bersih dan diamkan hingga 72 jam untuk menghindari terjadinya kontaminasi.

2. Pengemasan hand sanitizer ke dalam botol kecil.

3. Analisis hasil pembuatan hand sanitizer setelah kegiatan berlangsung

4. Penyusunan laporan pengabdian

5. Publikasi di media televisi dan media cetak

\section{Hasil dan Pembahasan}

Kegiatan pengabdian ini dilaksanakan di awal pandemi untuk mengurangi dampak dari virus COVID-19. Selama pandemi, pemerintah melarang masyarakat untuk sering keluar rumah. Tetapi dengan berbagai aktivitas yang tetap harus dilakukan serta tuntutan ekonomi, masyarakat tetap melaksanakan kegiatan di luar rumah. Dengan berbagai kesibukan yang ada, masyarakat jadi sulit untuk menjaga kesehatan dengan mencuci tangan menggunakan sabun ketika berada di tempat umum. Hal ini menjadikan penggunaan hand sanitizer menjadi salah satu alternatif untuk menjaga kesehatan tangan ketika berada diluar (Rahmatul, dkk, 2021). Kegiatan ini selain memberikan hasil berupa hand sanitizer siap pakai juga dapat membantu mahasiswa dalam mengajarkan dan mendampingi mereka tentang bagaimana pembuatan hand sanitizer yang dikombinasikan dengan bahan alami yaitu aloevera sehingga hand sanitizer yang dihasilkan lebih beraroma dan aman di kulit. Hand sanitizer yang diprodusi ini aman digunakan karena diproduksi berdasarkan resep dari Bahan Pengawasan Obat dan Makanan (BPOM).

Kegiatan ini dilaksanakan di laboratorium Marine Chemistry Universitas Maritim Raja Ali Haji. Pembuatan produk hand sanitizer dilakukan oleh dosen Pendidikan Kimia dengan mendampingi mahasiswa prodi Pendidikan Kimia, Universitas Maritim Raja Ali Haji. Pengabdian dilaksanakan mulai dari sterilisasi peralatan dan penyediaan bahan baku. Persiapan awal kegiatan laboratorium bisa dilihat pada Gambar 1 . Peralatan harus disterilkan terlebih dahulu untuk mencegah adanya kontaminasi bakteri yang dapat mengganggu dalam proses pembuatan hand sanitizer nantinya. Proses ini harus selalu dilakukan di awal untuk setiap kegiatan di laboratorium kimia.

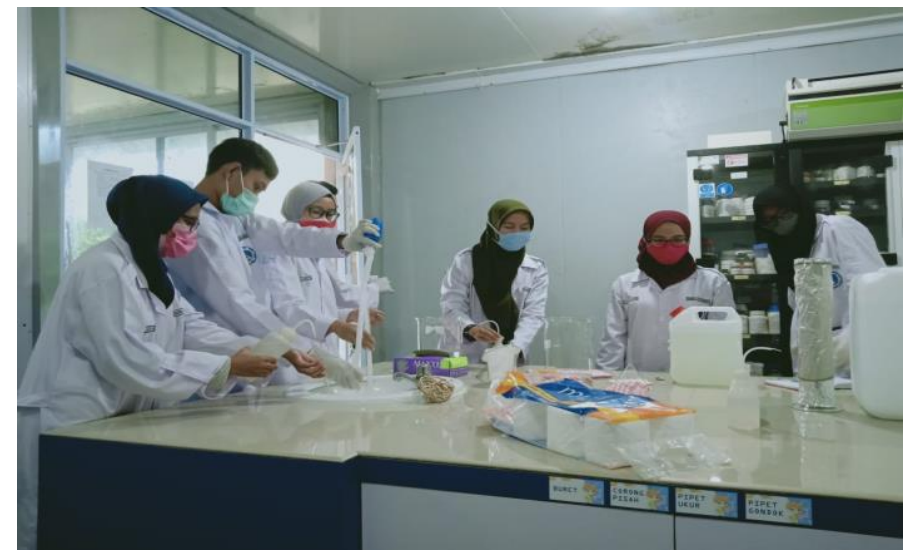

Gambar 1. Persiapan alat dan bahan 
Penyiapan resep bahan untuk membuat hand sanitizer yaitu pertama penimbangan aloe vera sebanyak 14,5 gr sebagai pengganti gliserol yang dapat melembabkan kulit, sehingga kulit tidak terasa kering saat menggunakan hand sanitizer ini. Selanjutnya menyiapkan alkohol sejumlah $833 \mathrm{~mL}$ menggunakan gelas ukur yang berukuran $1000 \mathrm{~mL}$ seperti pada Gambar 2. Alkohol dengan jenis etanol dan isopropanol dalam konsentrasi yang penuh maupun yang diencerkan hingga 30-40\% dari konsentrasi penuh terbukti dapat membunuh kuman yang berada di kulit karena aktivitas alkohol yang dapat melawan virus COVID-19 (Leslie, dkk, 2021).

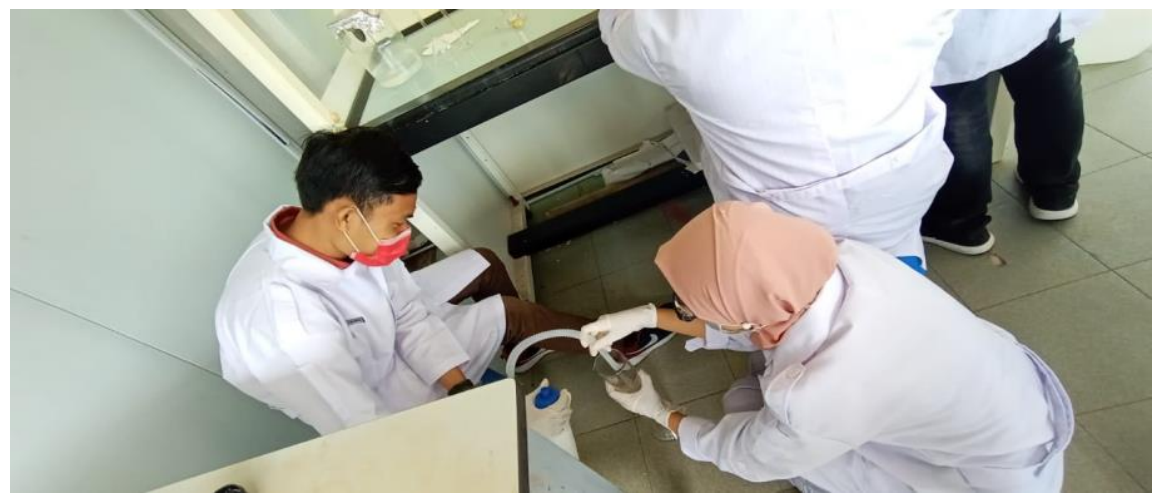

Gambar 2. Persiapan etanol 96\%

Sebanyak 41,7 mL hidrogen peroksida 3\% juga disiapkan dengan menggunakan gelas ukur 25 $\mathrm{mL}$ seperti pada Gambar 3. Fungsi dari hidrogen peroksida adalah sebagai antiseptik yang dapat menahan pertumbuhan mikroba. Hidrogen peroksida digunakan dalam hand sanitizer bertujuan untuk menghambat perkembangan mikroba sehingga hand sanitizer dapat digunakan dalam waktu yang lama.

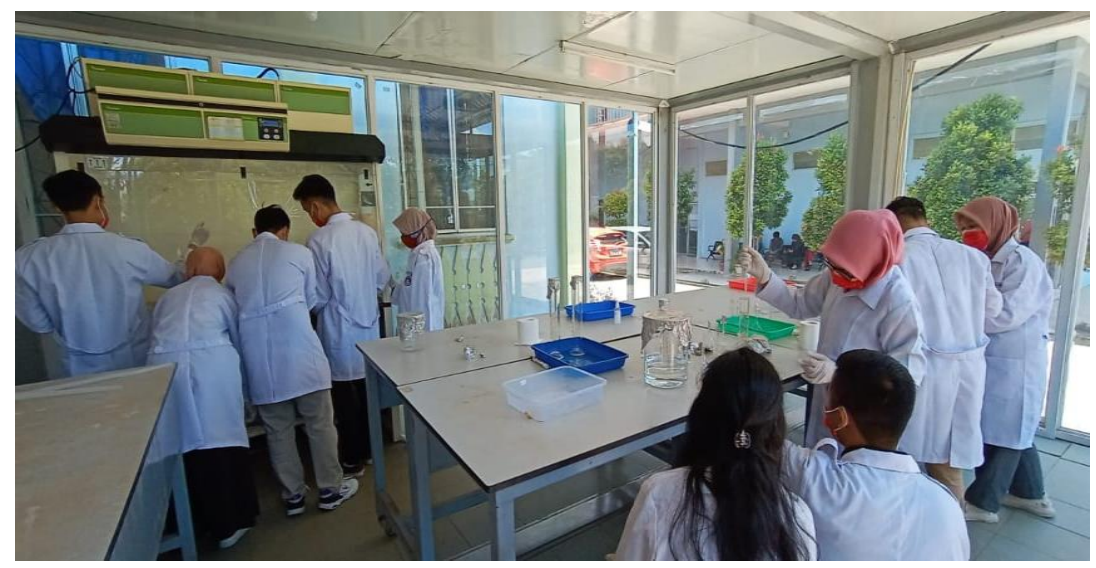

Gambar 3. Persiapan hidrogen peroksida 3\%

Selanjutnya, prosedur pencampuran bahan diawali dengan menambahkan hidrogen peroksida dengan kadar $3 \%$ sebanyak $41,7 \mathrm{~mL}$ ke dalam senyawa alkohol. Kemudian menambahkan aloe vera sebanyak 14.5gr serta memaksimalkan dengan air suling sampai $1000 \mathrm{~mL}$. Penggunaan alovera sebagai bahan alami pada hand sanitizer karena bahan alami ini selain dapat memberikan aroma yang wangi terhadap produk, ia juga dapat mengurangi bahaya toksik yang disebabkan oleh reaksi bahan kimia serta lebih ramah lingkungan (Alghamdi, 2021). Selanjutnya campuran diaduk hingga bercampur rata. Pencampuran bahan-bahan ini dilakukan didalam lemari asam untuk mencegah uap alkohol mengkontaminasi ruangan laboratorium seperti pada Gambar 4. 


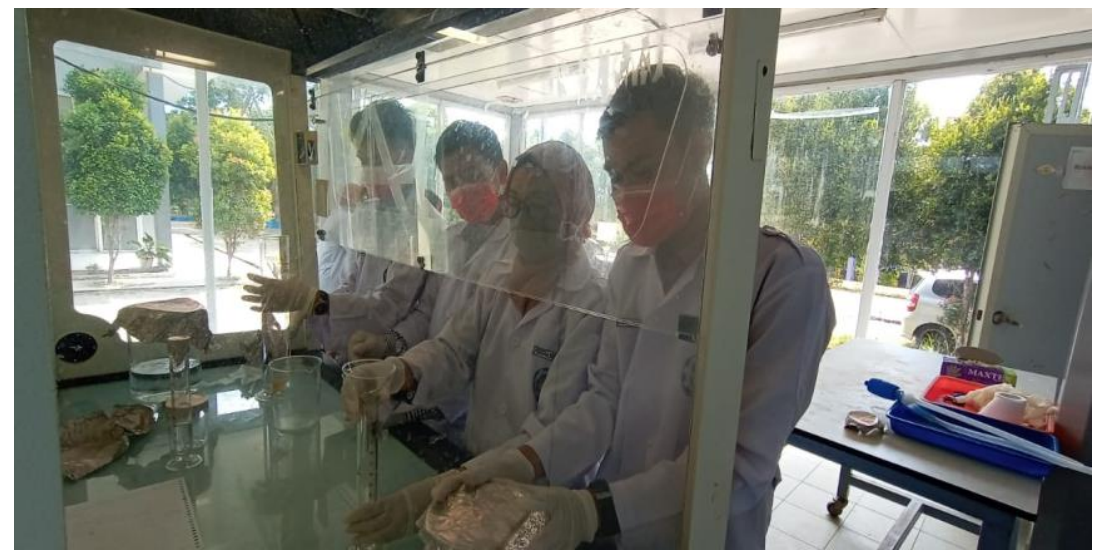

Gambar 4. Pencampuran di lemari asam

Campuran dipindahkan ke dalam jeriken yang sudah disiapkan selama sekitar 3 hari atau 72 jam, dengan tujuan untuk menghindari terjadinya kontaminasi. Setelah disimpan selama 72 jam, produk hand sanitizer di kemas kedalam botol-botol kecil berukuran $25 \mathrm{~mL}$ sampai $100 \mathrm{~mL}$ seperti pada Gambar 5. Pembuatan hand sanitizer rumahan sebaiknya dihindari karena tidak dapat mengukur bahan-bahan secara akurat serta kondisi yang tidak steril. Penggunaan hand sanitizer harus dijauhkan dari jangkauan anak-anak serta perlu didampingi orang dewasa ketika menggunakannya. Hand sanitizer sebaiknya digunakan pada jumlah yang cukup pada tangan yang tidak basah dan dioleskan hingga kering (Hakimi \& Armstrong, 2020).

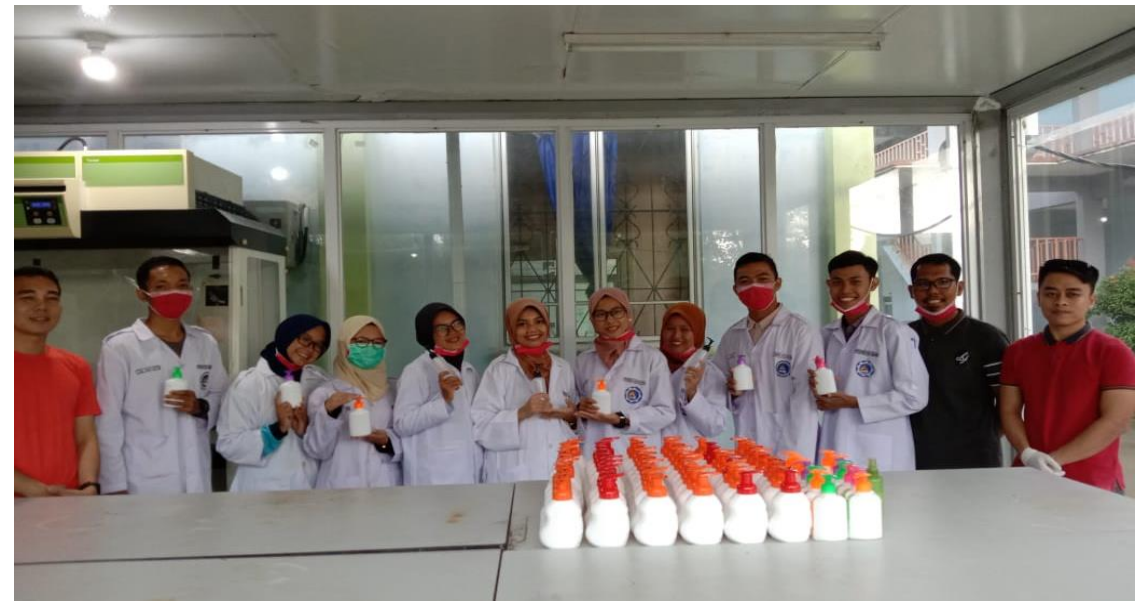

Gambar 5. Pengemasan hand sanitizer

Setelah pengemasan selesai produk hand sanitizer siap didistribusikan. Hasil produk hand sanitizer ini didistribusikan kepada satgas Kota Tanjungpinang, yayasan kesehatan masyarakat, puskesmas dan baznas Kota Tanjungpinang. Selain itu, kegiatan ini juga telah dipublikasikan di berbagai media televisi dan media cetak, salah satunya yaitu dipublikasikan dalam berita acara TV One dan TV Tanjungpinang seperti pada Gambar 6. Hasil hand sanitizer ini diharapkan dapat digunakan dengan baik oleh masyarakat melalui pendidikan karakter yang sudah tertanam di kehidupan masyarakat, karena dengan adanya pendidikan karakter ini masyarakat dapat menerapkan pengetahuan dan pengalaman yang didapat dan bisa diaplikasikan dengan baik oleh masyarakat serta lingkungannya (Malik, dkk, 2020). 


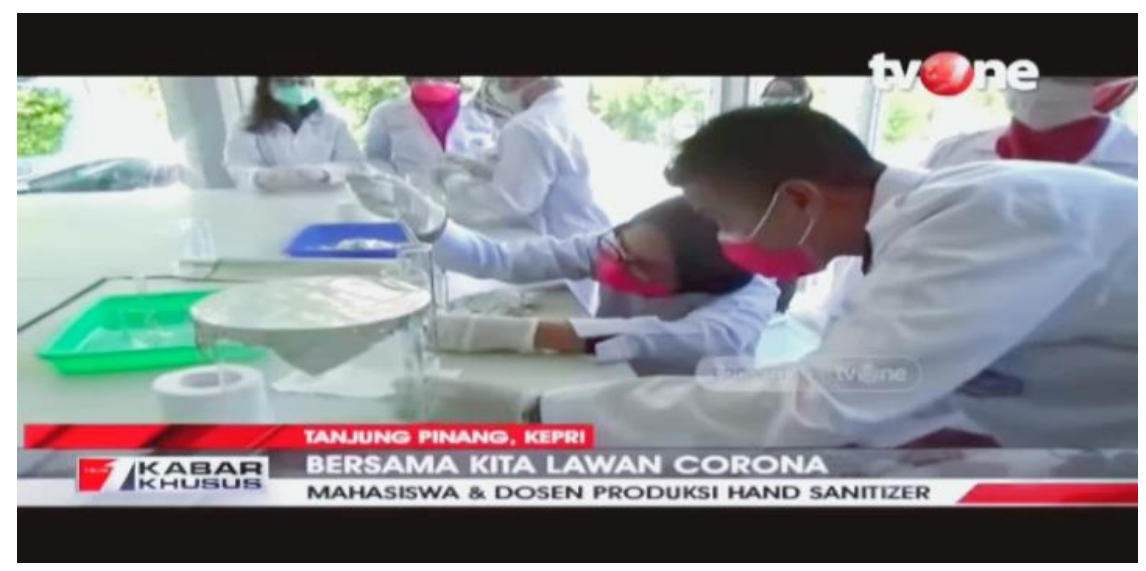

Gambar 6. Publikasi media televisi

Selanjutnya publikasi juga terdapat pada media cetak Tribun Batam seperti pada Gambar 7. Sehingga hasil dari kegiatan ini juga diketahui oleh masyarakat di kota Tanjungpinang dan sekitarnya. Kegiatan pengabdian ini dilakukan untuk membantu penyediaan hand sanitizer yang langka dan sangat dibutuhkan oleh masyarakat kota Tanjungpinang, sehingga dengan adanya pembuatan hand sanitizer ini semoga dapat membantu kebutuhan masyarakat akan hand sanitizer sekaligus membantu memutus penyebaran virus COVID-19 di kota Tanjungpinang.

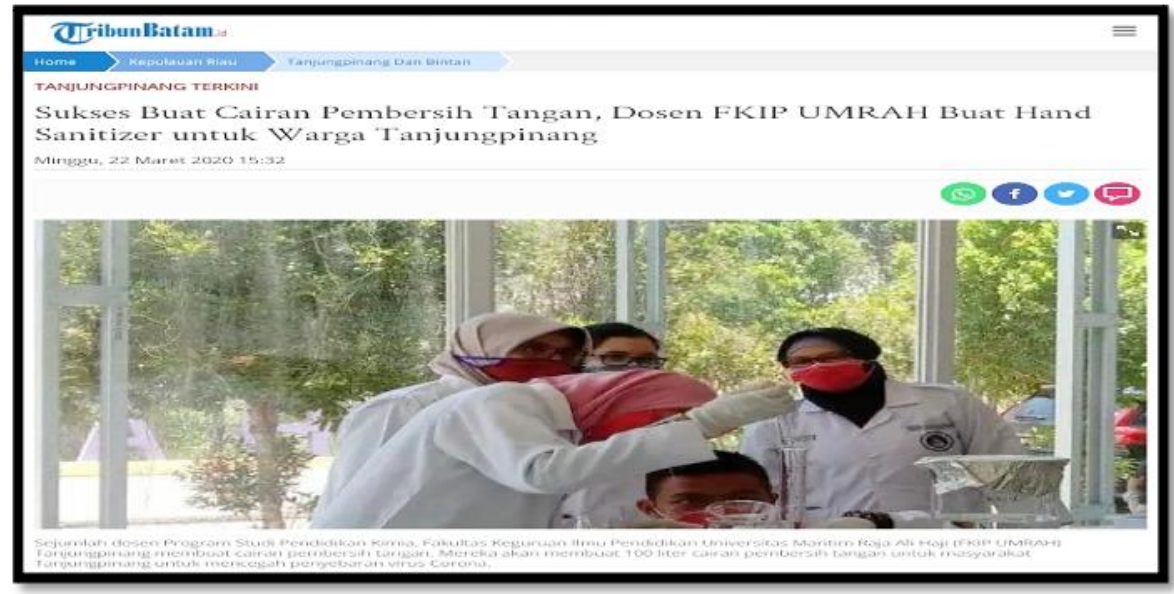

Gambar 7. Publikasi media cetak

\section{Kesimpulan}

Kegiatan Pengabdian Kepada Masyarakat (PKM) merupakan suatu kegiatan yang dilaksanakan untuk membantu masyarakat dengan tujuan memberikan berbagai ilmu dalam bentuk praktik. Pengabdian yang bertema Pendampingan Pembuatan Hand Sanitizer pada Mahasiswa Pendidikan Kimia pasca pandemi COVID-19 di Kota Tanjungpinang ini menjadi kegiatan yang dapat membantu permasalahan mayarakat akan terbatasnya hand sanitizer dimasa COVID-19 di Tanjungpinang. Semoga dengan adanya pengabdian ini juga dapat membantu memutuskan penyebaran COVID-19 di Kota Tanjungpinang. 


\section{Saran}

Kegiatan seperti dapat dilakukan di berbagai lokasi atau daerah sehingga masyarakat luas dapat memahami tentang pembuatan hand sanitizer. Perlu adanya koordinasi yang lebih baik lagi bagi akademisi, aparat negara dan masyarakat dalam menyukseskan kegiatan pengabdian ini.

\section{Ucapan Terima Kasih}

Penulis mengucapkan terima kasih bagi pihak-pihak yang telah berkontribusi pada pengabdian ini terutama pada dosen dan mahasiswa program studi Pendidikan Kimia serta Universitas Maritim Raja Ali Haji atas bantuan dana dan dukungan lainnya sehingga dapat dilaksanakan dengan baik dan memberikan kontribusi yang bermanfaat bagi pihak universitas dan kota Tanjungpinang.

\section{Referensi}

Alghamdi, H. A. (2021). A need to combat covid-19; herbal disinfection techniques, formulations and preparations of human health friendly hand sanitizers. Saudi Journal of Biological Sciences, xxx, 15 .

Andhani, L., Mayadi, Setiawati, S., \& Ramdhania, K. F. (2020). Sosialisasi media sosial dan pembuatan hand sanitizer, hand soap dalam rangka ikut serta menanggulangi COVID-19. Jurnal Sains Teknologi dalam Pemberdayaan Masyarakat (JSTPM), 1(1), 11-18.

Ervianingsih, Astaril, C., Zahran, I., Hurria, Mursyid, M., \& Samsi, A. S. (2020). Pencegahan COVID-19 dengan pembuatan dan pembagian hand sanitizer di Universitas Muhammadiyah Palopo. Jurnal Pengabdian kepada Masyarakat, 1(4), 44-48.

Fatimah, C., \& Ardiani, R. (2018). Pembuatan hand sanitizer (pembersih tangan tanpa air) menggunakan antiseptik bahan alami. Prosiding Seminar Nasional Hasil Pengabdian (pp. 336-343).

Hakimi, A. A., \& Armstrong, W. B. (2020). Hand sanitizer in a pandemic : wrong formulations in the wrong hand. Thr Journal of Emergency Medicine, 59(5), 668-672.

Leslie, R. A., Zhou, S. S., \& Macinga, D. R. (2021). Inactivation of sars-cov-2 by commercially available alcohol-based hand sanitizers. American Journal of Infection Control, 49, 401-402.

Malik, A., Shanty, I. L., \& Pardi, H. (2020). Sosialisasi pendidikan karakter di lingkungan keluarga masyarakat kampung bugis, Kota Tanjungpinang. Jurnal Anugerah, 2(2), 67-74.

Radji, M., Suryadi, H., \& Ariyanti, D. (2007). Uji aktivitas antimikroba beberapa merek dagang pembersih tangan antiseptik. Majalah Ilmu Kefarmasian, 4(1), 1-6.

Rahmatul, F., Halimatussakdiah, Fajar, B. A., \& Jofrishal. (2021). pelatihan pembuatan hand sanitizer (hanzer) menggunakan ekstrak daun halban (vitex pinnata linn) dan lidah buaya (aloe vera) dalam upaya pencegahan penyebaran COVID-19 di Desa Kotalintang Kabupaaten Aceh Tamiang. MARTABE : Jurnal Pengabdian Masyarakat, 4(1), 152-158.

Syafrida, S. (2020). Bersama melawan virus COVID-19 di Indonesia. SALAM : Jurnal Sosial dan Budaya Syar-i, 7(6), 495-508.

Telaumbanua, D. (2020). Urgensi pembentukan aturan terkait pencegahan COVID-19 di Indonesia. QALAMUNA : Jurnal Pendidikan, Sosial dan Agama, 12(1), 59-70. 